\title{
Effects of soil, altitude, rainfall, and distance on the floristic similarity of Atlantic Forest fragments in the east-Northeast
}

\author{
José Lima Rosa Neto ${ }^{1 *}$ \\ Ulysses Gomes Cortez Lopes ${ }^{2}$ \\ Flávia de Barros Prado Moura ${ }^{3}$
}

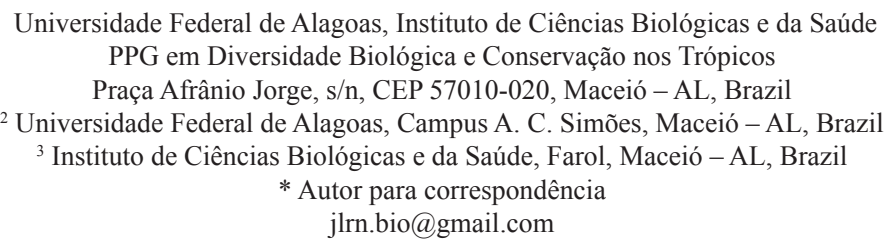

Submetido em 19/09/2012

Aceito para publicação em 19/04/2013

\section{Resumo}

Efeitos de solo, altitude, precipitação e distância sobre a similaridade florística de fragmentos de Mata Atlântica no Nordeste oriental. Este artigo apresenta os resultados de um levantamento florístico realizado em um fragmento de Mata Atlântica no estado de Alagoas. Além disso, os resultados de uma análise de similaridade entre dez fragmentos de floresta tropical do Nordeste oriental brasileiro são apresentados. A comparação florística foi baseada em dados binários em relação ao critério de presença/ausência para espécies de árvores identificadas nos dez fragmentos por meio do índice de similaridade de Sørensen. Um dendograma foi elaborado utilizando análise de agrupamento (índice de Jaccard) e análise de correspondência canônica (ACC) para testar os fatores abióticos, que podem influenciar de forma diferente a similaridade dos fragmentos. Os fragmentos apresentaram índices de similaridade baixa. As variações deveram-se ao fato de cada fragmento ser um pedaço do que uma vez foi uma região contínua e heterogênea. No entanto, a perda de diversidade, incluindo o desaparecimento de espécies mais exigentes, pode levar, em grande escala, à homogeneidade e simplificação da Mata Atlântica nordestina.

Palavras-chave: Fragmentação; Homogeneização; Perda de biodiversidade; Redução de hábitat

\section{Abstract}

This paper presents the results of a floristic survey conducted on an Atlantic Forest fragment in the state of Alagoas, Brazil. Besides, the results of a similarity analysis between ten rainforest fragments from the Brazilian east-Northeast are presented. The floristic comparison was based on binary data with regard to the presence/ absence criterion for tree species identified in the ten fragments by means of Sørensen's similarity index. A dendrogram was prepared using cluster analysis (Jaccard's index) and canonical correspondence analysis (CCA) to test the abiotic factors, which can differently influence the similarity of fragments. The fragments showed low similarity indices. The variations were due to the fact that each fragment is a patch of what once was a continuous and heterogeneous region. However, the diversity loss, including the disappearance of more demanding species, can lead, in large-scale, to homogeneity and simplification of the northeastern Atlantic Forest.

Key words: Biodiversity loss; Fragmentation; Habitat reduction; Homogenization 


\section{Introduction}

The east-Northeast Atlantic Forest originally covered the hydrographic region of the same name, which comprises the east-Northeast portion and the northern Sao Francisco River (Figure 1). It corresponds to an important endemism center (RIBEIRO et al., 2009) and, nowadays, it's among the most threatened areas in the world (MYERS et al., 2000).

Pifano et al. (2007) stated, pointing out variations in the floristic physiognomy, that, associated to the various topographic regions, several soil types lead to an increase in density and presence or absence of certain floristic species groups.

According to the numerous variations, studies on floristic similarity of fragments evidence significant heterogeneity, even between areas under similar climatic, geomorphological, and topographic conditions (URBANETZ et al., 2010).

Knowing the species distribution patterns is essential in order to define policies for conservation in the current fragmentation scenario of the northeastern Atlantic Forest. Thus, this study presents a floristic survey based on primary data from a forest fragment in the state of Alagoas, in addition to a similarity analysis between ten northeastern Atlantic Forest fragment, aiming to illustrate the influence of variables such as soil, rainfall, altitude, and distance on the floristic similarity of these fragments.

\section{Material and Methods}

\section{Study area}

The Varrela fragment is located at the town of Pilar, in the state of Alagoas, Brazil ( $\left.9^{\circ} 42^{\prime} \mathrm{S} / 36^{\circ} 00^{\prime} \mathrm{W}\right)$; it has 646.64ha and belongs to the sugar mill of the Carlos Lyra Group. The forest is located at a hilly area with Oxisol and $100 \mathrm{~m}$ altitude, average rainfall of $2,000 \mathrm{~mm}$, and it's classified as lowland open tropical rainforest (VELOSO et al., 1991).

\section{Data set and analysis}

The collections were weekly performed within the period from August 2007 to February 2010. The various fragment habitats (edges, paths, core, valleys, and streams) were went through in search of individuals at the reproductive phase. The specimens were deposited in the herbarium of the Natural History Museum of Universidade Federal de Alagoas (NHM/UFAL).

One attributed an identification key to each family, there were comparisons to materials from the herbarium

FIGURE 1: East-Northeast region (in gray). In detail, the studied fragment position (Varrela fragment) and the other nine fragments taken into account for floristic similarity analysis.

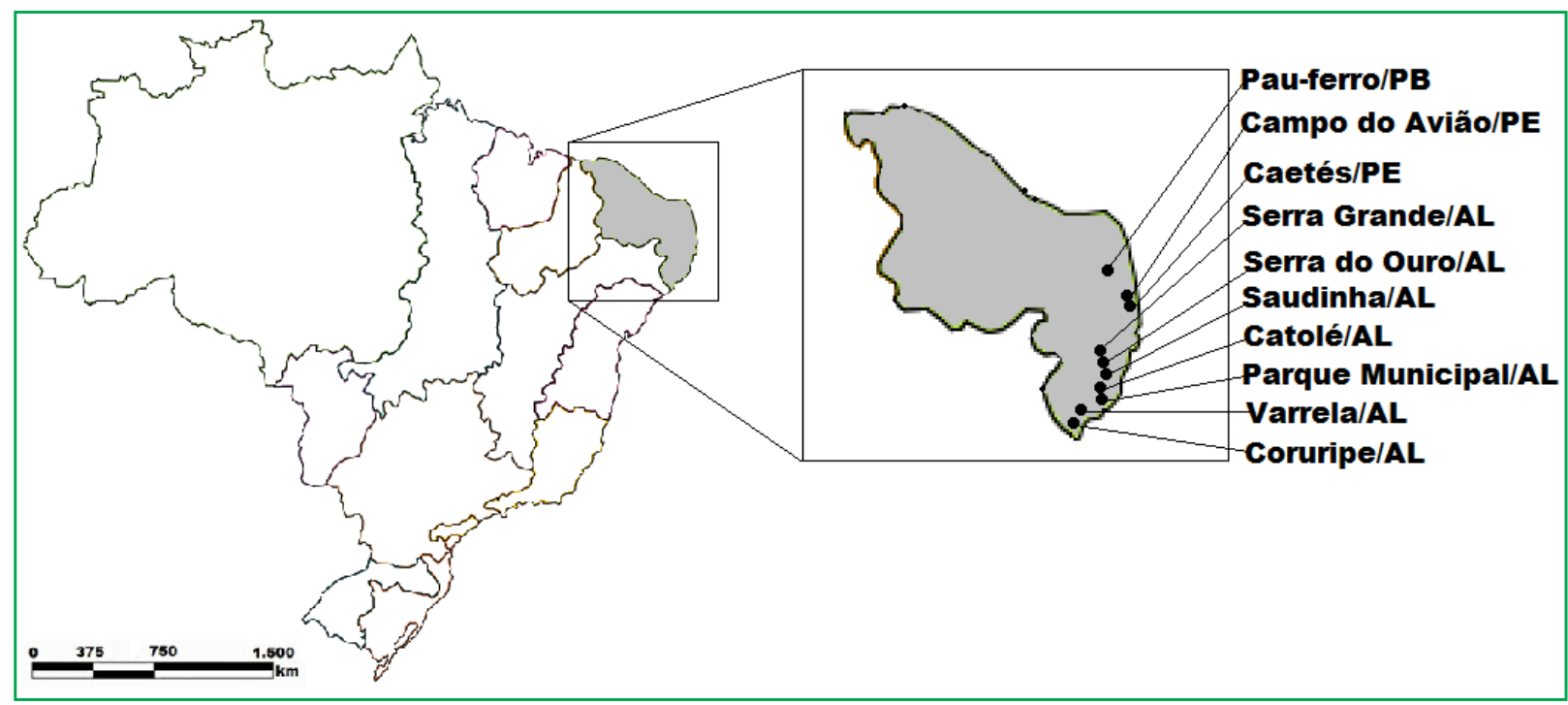


of NHM/UFAL and reading of specialized literature (LORENZI 1990, 1992, 2002; SOUZA; LORENZI, 2005) and the species list included into the Guide of Tropical Plants (www.fieldmuseum.org). The taxonomic nomenclature is according to the APG II (2003).

The fragment's floristic composition was compared to nine other surveys performed in the east-Northeast Atlantic Forest, which had their distances measured according to coordinates; from these points, distance $(\mathrm{km})$ straight lines were drawn on a Google Earth map. The use of unpublished data was due to lack of published material addressing the state of Alagoas. It's noteworthy that all botanical material from this studies is deposited in the herbaria UFP of Universidade Federal de Pernambuco (UFPE) (Serra Grande) and MAC of the Environment Institute of the State of Alagoas (IMA/AL) (Serra do Ouro, Catole, Municipal Park of Maceio and Coruripe) and it may be accessed at the online database of the speciesLink.
The floristic comparison was performed through presence/absence binary data with regard to the tree species identified in ten forest areas (Table 1), using Sørensen's similarity index, which attributes greater weight to usual species, and correlation test between distance and similarity. A dendrogram was prepared through cluster analysis (Jaccard's index) and canonical correspondence analysis (CCA), in order to test abiotic factors, which can differently influence the fragments' similarity. The analyses were conducted on the software PAST 2.08.

\section{Results and Discussion}

In the Varrela fragment, 74 tree species were identified, belonging to 65 genera and 32 families (Table 2 ). There was a predominance of the families Fabaceae (14), Lecythidaceae (5), and Malvaceae, Myrtaceae, Rubiaceae, and Sapindaceae (4), which made up 47.3\% of the floristic composition.

TABLE 1: Description of the fragments with regard to their location, richness, area, altitude, rainfall, and soil type. Pau-Ferro (PF), Campo do Aviao (CP), Caetes (CA), Serra Grande (SG), Serra do Ouro (SO), Saudinha (SD), Catole (CT), Municipal Park (MP), Coruripe (CR). Podzolic Soil (P) and Oxisol (O). *Assis (2000).

\begin{tabular}{|c|c|c|c|c|c|c|c|c|}
\hline Area & Location (state) & Coordinates & $\begin{array}{c}\text { Number } \\
\text { of species }\end{array}$ & $\begin{array}{l}\text { Area } \\
\text { (ha) }\end{array}$ & $\begin{array}{c}\text { Altitude } \\
(\mathrm{m})\end{array}$ & $\begin{array}{c}\text { Rainfall } \\
(\mathrm{mm})\end{array}$ & Soil & Author \\
\hline $\mathrm{PF}$ & Areia (PB) & $06^{\circ} 58^{\prime} \mathrm{S} / 35^{\circ} 42 \mathrm{~W}$ & 75 & 600 & 600 & $1,450.00$ & $\mathrm{P}$ & Oliveira et al. (2006) \\
\hline $\mathrm{CP}$ & Igarassu (PE) & $07^{\circ} 49^{\prime} \mathrm{S} / 34^{\circ} 59^{\prime} \mathrm{W}$ & 86 & 474 & 110 & $1,594.87$ & $\mathrm{O}$ & Rocha et al. (2008) \\
\hline $\mathrm{CA}$ & Paulista (PE) & $07^{\circ} 55^{\prime} \mathrm{S} / 34^{\circ} 55^{\prime} \mathrm{W}$ & 90 & 157 & 90 & $1,450.00$ & $\mathrm{P}$ & Pessoa et al. (2009) \\
\hline $\mathrm{SG}$ & Ibateguara (AL) & $08^{\circ} 30^{\prime} \mathrm{S} / 35^{\circ} 50^{\prime} \mathrm{W}$ & 190 & 8,000 & 500 & $1,250.00$ & $\mathrm{O} / \mathrm{P}$ & Oliveira et al. (2004) \\
\hline SO & Murici (AL) & $09^{\circ} 13^{\prime} \mathrm{S} / 33^{\circ} 50^{\prime} \mathrm{W}$ & 57 & 81 & 450 & $2,000.00$ & $\mathrm{P}$ & Pinheiro (2006) \\
\hline $\mathrm{SD}$ & Maceio (AL) & $09^{\circ} 22^{\prime} \mathrm{S} / 35^{\circ} 45^{\prime} \mathrm{W}$ & 73 & $1,210^{*}$ & $304^{*}$ & $1,900.00$ & $\mathrm{P}^{*}$ & Costa et al. (2007) \\
\hline $\mathrm{CT}$ & Satuba (AL) & $09^{\circ} 34^{\prime} \mathrm{S} / 35^{\circ} 36^{\prime} \mathrm{W}$ & 65 & 5,415 & 150 & $1,750.00$ & $\mathrm{O}$ & Rodrigues (2002) \\
\hline MP & Maceio (AL) & $09^{\circ} 35^{\prime} \mathrm{S} / 35^{\circ} 46^{\prime} \mathrm{W}$ & 72 & 82.4 & 75 & $1,900.00$ & $\mathrm{O}$ & Fonseca (2006) \\
\hline $\mathrm{CR}$ & Coruripe (AL) & $10^{\circ} 18^{\prime} \mathrm{S} / 36^{\circ} 05^{\prime} \mathrm{W}$ & 111 & 5,929 & 60 & $1,487.00$ & $\mathrm{O}$ & Machado et al. (2012) \\
\hline VR & Pilar (AL) & $9^{\circ} 42^{\prime} \mathrm{S} / 36^{\circ} 00^{\prime} \mathrm{W}$ & 74 & 646.64 & 100 & $2,000.00$ & $\mathrm{O}$ & This study \\
\hline
\end{tabular}


TABLE 2: List of tree species occurring in the Varrela fragment in Pilar, Alagoas, Brazil.

\begin{tabular}{|c|c|c|}
\hline Family & Species & Popular name \\
\hline \multirow[t]{3}{*}{ Anacardiaceae } & Spondia venulosa Mart. ex Engl. & Cajazeiro \\
\hline & Tapirira guianensis Aubl. & Cupiuba branca \\
\hline & Thyrsodium spruceanum Salzm. ex Benth. & Caboata-de-leite \\
\hline \multirow[t]{2}{*}{ Annonaceae } & Annona cacans Warm. & Araticum \\
\hline & Xylopia frutescens Aubl. & Pindaiba \\
\hline Apocynaceae & Himatanthus phagedaenicus (Mart.) Woodson & Banana-de-papagaio \\
\hline Araliaceae & Schefflera morototoni (Aubl.) Maguire, Steyerm. \& Frodin & Sambaquim \\
\hline \multirow[t]{2}{*}{ Arecaceae } & Bactris ferruginea Burret & Tucum \\
\hline & Elaeis guineensis L. & Dende \\
\hline \multirow[t]{3}{*}{ Boraginaceae } & Cordia sellowiana Cham. & Chapeu-de-sol \\
\hline & Cordia superba Cham. & Uva-de-raposa-branca \\
\hline & Cordia nodosa Lam. & Uva-de-raposa-vermelha \\
\hline Burseraceae & Protium heptaphyllum (Aubl.) Marchand & Amescla \\
\hline Cannabaceae & Trema micrantha (L.) Blume & Camarao \\
\hline Caricaceae & Jacaratia spinosa (Aubl.) A. DC. & Jaracatia \\
\hline Celastraceae & Maytenus distichophylla Mart. ex Reissek & - \\
\hline Chrysobalanaceae & Hirtella racemosa Lam. & - \\
\hline \multirow[t]{2}{*}{ Clusiaceae } & Clusia nemorosa G. Mey. & Pororoca \\
\hline & Symphonia globulifera L. F. & Bulandi \\
\hline Connaraceae & Connarus punctatus Planch. & - \\
\hline Euphorbiaceae & Sapium glandulatum Pax & Burra-leiteira \\
\hline \multirow[t]{14}{*}{ Fabaceae } & Apuleia leiocarpa (Vogel) J. F. Macbr & Jitai-amarelo \\
\hline & Abarema cochliacarpos (Gomez) Barneby \& J. W. Grimes & Barbatimao \\
\hline & Bowdichia virgilioides Kunth. & Sucupira-branca \\
\hline & Caesalpinia echinata Lam. & Pau-brasil \\
\hline & Chamaecrista ensiformis (Vell.) H. S. Irwin \& Barneby & Coração-de-negro \\
\hline & Copaifera langsdorffii Desf. & Pau-d'oleo \\
\hline & Dialium divaricatum Vahl. & Pininga \\
\hline & Hymenaea martiana Hayne & Jatoba \\
\hline & Inga laurina (Sw.) Willd. & Inga \\
\hline & Machaerium hirtum (Vell.) Stellfeld & Sucupira-preta \\
\hline & Parkia pendula (Willd.) Benth. ex Walp. & Visgueiro \\
\hline & Samanea tubulosa (Benth.) Barneby \& J. W. Grimes & Bordao-de-velho \\
\hline & Stryphnodendron pulcherrimum (Willd.) Hochr. & Favinha \\
\hline & Swartzia flaemingii Raddi & Enxundia \\
\hline Hernandiaceae & Sparattanthelium botocudorum Mart. & Cabo-de-facao \\
\hline
\end{tabular}




\begin{tabular}{|c|c|c|}
\hline Hypericaceae & Vismia guianensis (Aubl.) Choisy & Lacre \\
\hline Lauraceae & Ocotea glomerata (Ness) Mez & Louro-tucano \\
\hline Lamiaceae & Vitex rufescens A. Juss. & Salgueiro, maria-preta \\
\hline \multirow[t]{5}{*}{ Lecythidaceae } & Cariniana legalis (Mart.) Kuntze & Jequitiba \\
\hline & Eschweilera ovata (Cambess.) Miers & Embiriba \\
\hline & Gustavia augusta L. & Jeniparana \\
\hline & Lecythis chartacea O. Berg. & Sapucaia-branca \\
\hline & Lecythis pisonis (Cambess.) Miers & Sapucaia-vermelha \\
\hline \multirow[t]{2}{*}{ Malpighiaceae } & Byrsonima sericea A. DC. & Murici \\
\hline & Byrsonima stipulacea A. Juss. & Murici-boi \\
\hline \multirow[t]{4}{*}{ Malvaceae } & Apeiba tibourbou Aubl. & Pau-de-jangada \\
\hline & Eriotheca crenulaticalyx A. Robyns & Munguba \\
\hline & Guazuma ulmifolia Lam. & Carrapicho \\
\hline & Luehea ochrophylla Mart. & Açoita-cavalo \\
\hline \multirow[t]{3}{*}{ Melastomataceae } & Miconia albicans (Sw.) Triana & Caramunde \\
\hline & Miconia ciliata (Rich.) DC. & Caramunde \\
\hline & Miconia ligustroides (DC) Naudin & Caramunde \\
\hline \multirow[t]{3}{*}{ Moraceae } & Brosimum guianense (Aubl.) Huber. & Quiri \\
\hline & Ficus gomelleira Kunth \& C. D. Bouché & Gameleira \\
\hline & Sorocea bonplandii Cogn. & Pau-de-teiu \\
\hline \multirow[t]{4}{*}{ Myrtaceae } & Campomanesia dichotoma (O. Berg) Mattos & Guabiraba \\
\hline & Myrcia alagoensis O. Berg. & - \\
\hline & Myrcia silvatica (G. Meyer) DC. & Murta-da-folha-pequena \\
\hline & Psidium araca Raddi. & Araca \\
\hline Nyctaginaceae & Guapira opposita (Vell.) Reitz & Pau-piranha \\
\hline Polygonaceae & Coccoloba mollis Casar. & Cabacu \\
\hline \multirow[t]{4}{*}{ Rubiaceae } & Coutarea hexandra (Jacq.) K. Schum. & - \\
\hline & Genipa americana L. & Jenipapo \\
\hline & Guettarda angelica Mart. ex Mull. Arg. & Angelica \\
\hline & Posoqueria latifolia (Rudge) Roem. \& Schult. & - \\
\hline \multirow[t]{4}{*}{ Sapindaceae } & Allophylus edulis (A. St.-Hil., A. Juss. \& Cambess.) Radlk. & - \\
\hline & Cupania oblongifolia Mart. & Caboata \\
\hline & Talisia elephantipes Sandwith \& Tutin & Pitomba-da-mata \\
\hline & Talisia esculenta (Cambess.) Radlk. & Pitomba \\
\hline \multirow[t]{2}{*}{ Sapotaceae } & Pouteria grandiflora (A. DC.) Baehni & - \\
\hline & Pouteria pachycalyx T. D. Penn. & Guapeba \\
\hline Simaroubaceae & Simarouba amara Aubl. & Praiba, tamanqueira \\
\hline Urticaceae & Cecropia pachystachya Trécul & Embauba-de-capoeira \\
\hline
\end{tabular}


For the ten fragments, a total of 383 tree species were identified, distributed over 58 families. Among them, 5 species are common to all fragments: Schefflera morototoni, Protium heptaphyllum, Eschweilera ovata, Byrsonima sericea, and Apeiba tibourbou. Moreover, 118 species (30.81\%) had low frequency, occurring in only 1 fragment, evidencing a high heterogeneity among the fragments (URBANETZ et al., 2010), even those inserted in the same endemism center (MURRAYSMITH et al., 2008). Brandão et al. (2009) found in a phytosociological study that these species account for about $24.24 \%$ of the vegetation cover in an Atlantic forest fragment in the east-Northeast.

The analysis with regard to distance and similarity pointed out a negative correlation (e.g. REIS et al., 2007) (Figure 2). The cluster analysis (Figure 3 ) formed two fairly distinct groups of fragments. The first consisted of Varrela (VR/AL), Coruripe (CR/AL), Catole (CT/AL), and Municipal Park of Maceio (MPM), all with Oxisol soil and low altitude (up to $150 \mathrm{~m}$ ). The second group consisted of Serra do Ouro (SO/AL), Campo do Aviao (CP/PE), Caete (CA/PE), and Saudinha (SD/AL), with Podzolic soil formation, except for CP/PE.

Taking into account the ten fragments compared, Varrela and Coruripe had the greatest similarity, both for Sørensen's index (0.48) and Jaccard's index (Figure 3); both are fragments of from the state of Alagoas located $51 \mathrm{~km}$ away from each other, straight, and, according to Tavares et al. (1975), they're in an area named micro-region of Tabuleiro de Sao Miguel dos Campos. This floristic proximity may be due to recent fragmentation process that they underwent in the late 1960s (COIMBRA-FILHO; CAMARA, 2005) with regard to the separation of other areas, some of them for over a century.

The Campo do Aviao (CP) fragment, in the state of Pernambuco, there was an exception, since it was the only one in an Oxisol area which integrates with Podzolic fragments, and perhaps its floristic composition undergoes more influence from the proximity to the forest of Caetes-PE (CA) that, among the ten fragments, has the second smallest distance $(14 \mathrm{~km})$, in addition to present similar altitude levels (Table 1). This pattern is in agreement with that proposed by Whittaker et al. (2008), indicating that, for closer fragments, the soil may not be the first condition decisively interfering on the similarity or differentiation of their floras.

FIGURE 2: Correlation between similarity (Sørensen's index) and log distance $(\mathrm{km})$ of the ten fragments.

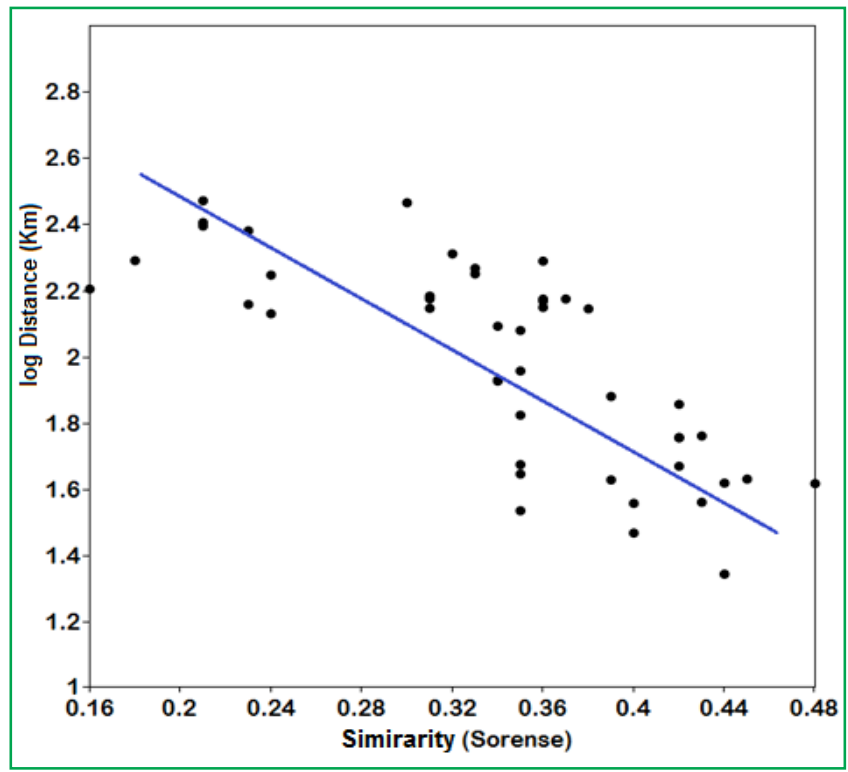

FIGURE 3: Cluster analysis using Jaccard's index, based on the presence/absence binary matrix for 383 tree species in ten east-Northeast Atlantic Forest areas.

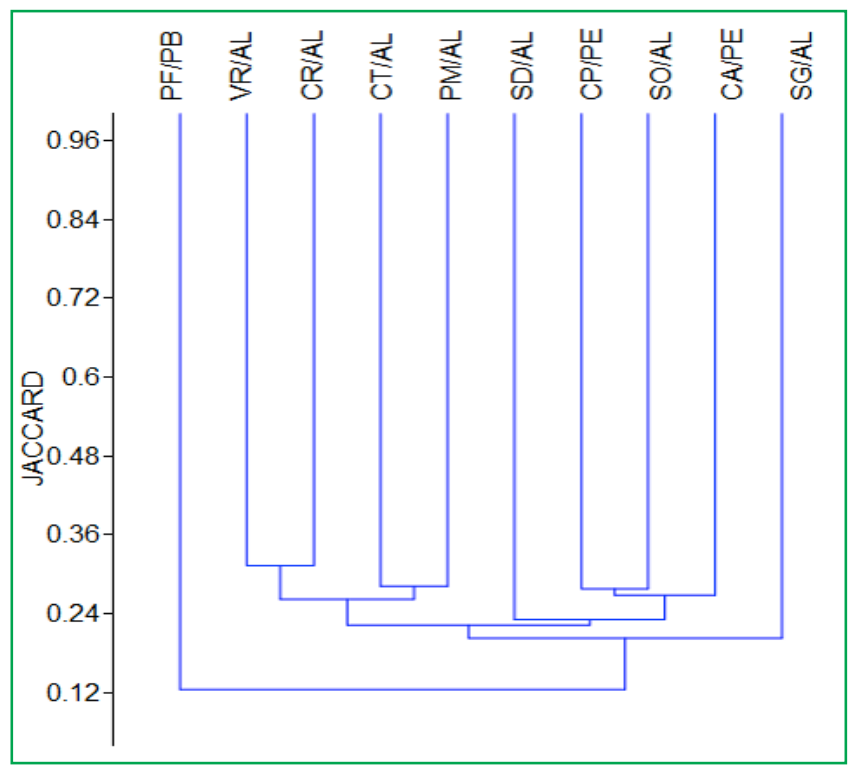

Among all locations, the of Pau-Ferro (PF) forest, in the state of Paraiba, presented the lowest similarity indices, Jaccard (0.12) and Sørensen (0.16); this statistical claim may be due to the fact that this is an area very close to the seasonal formation, something 
which can exert a strong influence on its composition. In addition, this area has the highest altitude $(600 \mathrm{~m})$ among all locations and, according to CCA (Figure 4), it's the most influential factor. Probably, it's an isolated fragment from the Quaternary climatic fluctuations, instead of a result due human influence, such as the other fragments. Hence, the isolation time may also affect this result.

FIGURE 4: Canonical correspondence analysis based on the presence/absence binary matrix for 383 tree species in ten east-Northeast Atlantic Forest areas.

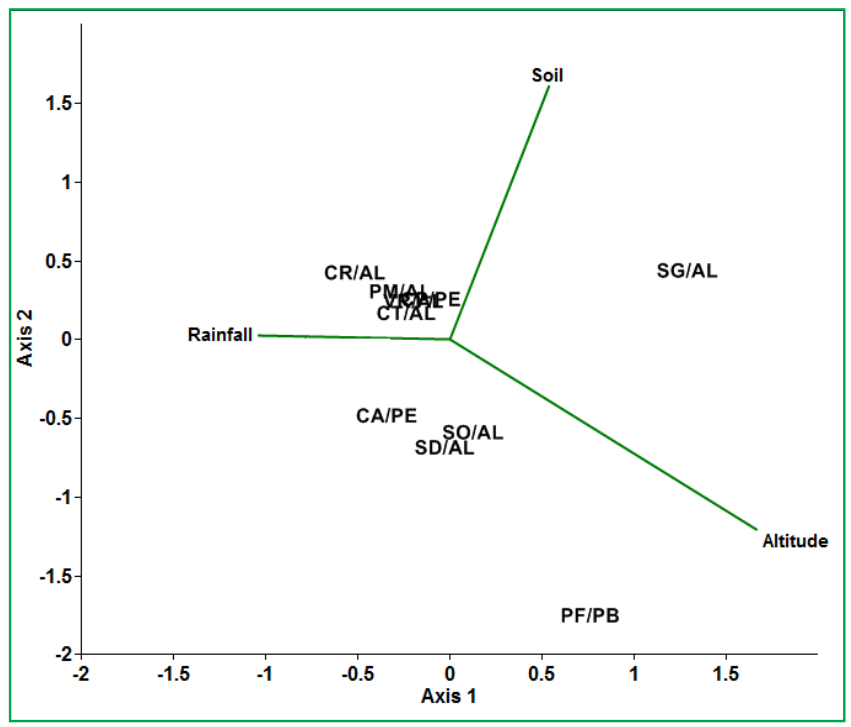

The Serra Grande (SG) fragment was, according to cluster analysis, close to the two groups, but not directly associated to any group; this characterization suggests particular aspects, because this is the only fragment with Oxisol and Podzolic formation in its area, and it's also the largest fragment, with higher number of species (Table 1) and endemism; the Caete-PE (0.39) and Campo do Aviao-PE (0.37) fragments were the most similar ones.

Therefore, according to Urbanetz et al. (2010), since all fragments had values below 0.5 for both indices, this indicates a low similarity among them. The CCA results (Figure 4) pointed out that, among the variables examined, the soil and rainfall were the most influential on the similarity/heterogeneity of the forests floristic composition, corroborating the results found by Botrel et al. (2002) and Ferraz et al. (2004).

The fragments had low similarity indices and this variation was due to the fact that each fragment is a subset of what once was a continuous and, perhaps, heterogeneous region. Nevertheless, the loss of this biodiversity, with the disappearance of more demanding species, according to Murray-Smith et al. (2008) and Santos et al. (2008), might cause a large-scale homogenization and simplification of the northeastern Atlantic Forest.

One of the most evident aspects of this study was the low floristic similarity, with more than $30 \%$ of species recorded in only one out of all analyzed fragments. The similarity indices were quite low, evidencing a high heterogeneity among the fragments. Regarding the examined variables, one may suggest that the soil type (Oxisol and Podzolic) and rainfall were crucial to the species distribution in the northeastern Atlantic Forest. Besides, the spatial distance assumes a primordial influence on similarity, which has a good inverse correlation with the similarity values of the fragments, overlaying the effect of other variables.

However, this evaluation sheds light on a small portion of the complex relation between floristic similarity and environmental factors of the fragments, suggesting the need for further studies aimed at fully characterizing the current similarity status of the northeastern Atlantic Forest fragments.

\section{Acknowledgments}

The authors thank the funding and structural support for this research by the sugar mill of the Carlos Lyra Group, as well as the support for field expeditions by the biologist José João Cláudio Costa de Miranda.

\section{References}

APG II. An update of the Angiosperm Phylogeny Group classification for the orders and families of flowering plants: APG II. Botanical Journal of the Linnean Society, London, v. 399-436, 2003.

ASSIS, J. S. Biogeografia e conservação da biodiversidade: projeções para Alagoas. Maceió: Edições Catavento, 2000. 200 p.

BOTREL, R. T.; OLIVEIRA-FILHO, A. T.; RODRIGUES, L. A.; CURI, N. Influência do solo e topografia sobre as variações da composição florística e estrutura da comunidade arbóreo-arbustiva de uma floresta estacional semidecidual em Ingaí, MG. Revista Brasileira de Botânica, São Paulo, v. 25, n. 2, p. 195-213, 2002.

BRANDÃO, C. F. L. S.; MARAGON, L. C.; FERREIRA, R. L. C.; SILVA, A. C. B. L. Estrutura fitossociológica e classificação 
sucessional do componente arbóreo em um fragmento de floresta atlântica em Igarassú - Pernambuco. Revista de Ciências Agrárias, Recife, v. 4, n. 1, p. 55-61, 2009.

COIMBRA-FILHO, A. F.; CAMARA, I. G. Os limites originais do bioma Mata Atlântica na região do nordeste do Brasil. 2. ed. Rio de Janeiro: Fundação Brasileira para a Conservação da Natureza, 2005. 96 p.

COSTA, A. S.; RIOS, P. A. F.; SALGADO, S. S., LYRA-LEMOS, R. P., MOURA, F. B. P. Estrutura de um Fragmento Florestal na Região Metropolitana de Maceió. Revista Brasileira de Biociências, Porto Alegre, v. 5, supl. 1, p. 340-342, 2007.

FERRAZ, E. M. N.; ARAÚJO, E. L.; SILVA, S. I. Floristic similarities between lowland and montane areas of Atlantic Coastal Forest in Northeastern Brazil. Plant Ecology, Dordrecht, n. 174, p. 59-70, 2004.

FONSECA, S. A. Levantamento florístico do Parque Municipal de Maceió, Alagoas. 2006. 73 f. Trabalho de Conclusão (Curso de Graduação em Ciências Biológicas) - Universidade Federal de Alagoas, Maceió. 2006.

LORENZI, H. Manual de indentificação e controle de plantas daninhas: plantio direto e convencional. 3. ed. Nova Odessa: Plantarum. 1990. 110 p.

LORENZI, H. Árvores brasileiras: manual de identificação e cultivo de plantas arbóreas nativas do Brasil. Nova Odessa: Platarum. 1992. 368 p.

LORENZI, H. Árvores brasileiras: manual de identificação e cultivo de plantas arbóreas nativas do Brasil. Vol. 2. 2 ed. Nova Odessa: Instituto Platarum. 2002. 384 p.

MACHADO, M. A. B. L.; CHAVES, L. de F. de C.; ROSA NETO, J. L.; LYRA-LEMOS, R. P. de. Florística do estrato arbóreo de fragmentos da mata atlântica do nordeste oriental, município de Coruripe, Alagoas, Brasil. Revista Ouricuri, Paulo Afonso: EDUNEB, v. 2, v. 2, p. 55-72, 2012.

MURRAY-SMITH, C.; BRUMMITT, N. A.; OLIVEIRA-FILHO, A. T.; BACHMAN, S.; Moat, J.; LUGHADHA, E. M. N.; LUCAS, E. J. Plant Diversity Hotspots in the Atlantic Coastal Forests of Brazil. Conservation Biology, San Francisco, vol. 23, n. 1, p. 151163, 2008.

MYERS, N.; MITTERMEIER, R. A.; MITTERMEIER, C. G. G.; FONSECA, A. B.; KENT, J. Biodiversity hotspots for conservation priorities. Nature, London, v. 403, p. 853-858, 2000.

OLIVEIRA, F. X.; ANDRADE, L. A.; FÉLIX, L. P. Comparações florísticas e estruturais entre comunidades de Floresta Ombrófila Aberta com diferentes idades, no Município de Areia, PB, Brasil. Acta Botanica Brasilica, Feira de Santana, v. 20, n. 4, p. 861-873, 2006.

OLIVEIRA, M.; TABARELLI, M.; GRILLO, A. Caracterização da flora dos remanescentes da Usina Serra Grande, Alagoas. Recife: Centro de Pesquisas Ambientais do Nordeste, 2004. 33 p. (Relatório Técnico)

PESSOA, L. M.; PINHEIRO, T. S.; ALVES, M. C. J. L.; PIMENTEL, R. M. M.; ZICKEL, C. S. Flora lenhosa em um fragmento urbano de floresta atlântica em Pernambuco. Revista de Geografia, Recife, v. 26, n. 3, p. 247-262, 2009.
PIFANO, D. S.; VALENTE, A. S. M.; CASTRO, R. M.; PIVARI, M. O. D.; SALIMENA, F. R. G.; OLIVEIRA-FILHO, A. T. Similaridade entre os habitats da vegetação do morro do imperador, juiz de fora, minas gerais, com base na composição de sua flora fanerogâmica. Rodriguésia, Rio de Janeiro, v. 58, n. 4, p. 885-904, 2007.

PINHEIRO, A. I. L. Levantamento florístico e fitossociológico da comunidade arbórea da Serra do Ouro na Estação Ecológica de Murici-AL. 2006. 89 f. Dissertação (Mestrado em Produção Vegetal) - Universidade Federal de Alagoas, Maceió. 2006.

REIS, H.; SCOLFORO, J. R. S.; OLIVEIRA, A. D. de; OLIVEIRA FILHO, A. T. de; MELLO, J. M. de. Análise da composição florística, diversidade e similaridade de fragmentos de mata atlântica em Minas Gerais. Cerne, Lavras, v. 13, n. 3, p. 280-290, 2007.

RIBEIRO, M. C.; METZGER, J. P; MARTENSEN, A. C.; PONZONI, F. J.; HIROTA, M. M. The Brazilian Atlantic Forest: How much is left, and how is the remainingforest distributed? Implications for conservation. Biological Conservation, Boston, V. 142, p. 1141-1153, 2009.

ROCHA, K. D.; CHAVES, L. F. C.; MARANGON, L. C.; SILVA, A. C. B. L. Caracterização da vegetação arbórea adulta em um fragmento de floresta atlântica, Igarassu, PE. Revista Brasileira de Ciências Agrárias, Recife, v. 3, n. 1, p. 35-41, 2008.

RODRIGUES, M. N. Levantamento florístico e análise da estrutura fitossociológica de um fragmento de Mata Atlântica na APA do Catolé, Municípios de Maceió e Satuba - Estado de Alagoas. 2002. 92 f. Dissertação (Mestrado em Produção Vegetal) - Universidade Federal de Alagoas, Maceió. 2002.

SANTOS, B. A.; PERES, C. A.; OLIVEIRA, M. A.; GRILlO, A.; ALVES-COSTA, C. P.; TABARELLI, M. Drastic erosion in functional attributes of tree assemblages in Atlantic Forest fragments of northeastern Brazil. Biological Conservation, v. 141, p. 249-260, 2008.

SOUZA, V. C.; LORENZI, H. Botânica sistemática: guia ilustrado para identificação das famílias de Angiosperma da flora brasileira. Nova Odessa: Instituto Platarum. 2005. 704 p.

TAVARES, S.; SOUZA TAVARES, E. J.; PAIVA, F. A. F.; CARVALHO, G. H. de. Nova contribuição para o inventário florestal de Alagoas. Recife: SUDENE - Div. Reprografia. Série Recursos Vegetais, 01, 1975. 114 p.

URBANETZ, C.; TAMASHIRO, J. Y.; KINOSHITA, L. S. Floristic composition and similarity analysis of an Atlantic rain forest fragment in Cananéia, São Paulo State, Brazil. Revista brasileira de Botânica, São Paulo, v. 33, n. 4, p. 639-651, 2010.

VELOSO, H. P.; RANGEL-FILHO, A. L. R.; LIMA, J. C. A. Classificação brasileira adaptada a um sistema universal. Departamento de Recursos Naturais e Estudos Ambientais. Rio de Janeiro: IBGE. 1991. 123 p

WHITTAKER, R. J.; TRIANTIS, K. A.; LADLE, R. J. A general dynamic theory of oceanic island biogeography. Journal of Biogeography, New York, n. 35, p. 977-994, 2008. 